International Journal of English Language Studies (IJELS)

ISSN: 2707-7578

DOI: $10.32996 /$ ijels

Website: https://al-kindipublisher.com/index.php/ijels

\title{
Enhancing Students' Confidence in an English Language Classroom
}

\author{
Alona Medalia Cadiz-Gabejan 8 (D) \\ Assistant Professor II, Samar State University, Catbalogan City, Samar, Philippines \\ $\triangle$ Corresponding Author: Alona Medalia Cadiz-Gabejan, E-mail: alonamedalia.gabejan@ssu.edu.ph
}

ARTICLE INFORMATION ABSTRACT

Received: April 08, 2021

Accepted: May 22, 2021

Volume: 3

Issue: 5

DOI: $10.32996 /$ ijels.2021.3.5.3

\section{KEYWORDS}

Confidence, Second Language

Learners, English, Language

Classroom
Second language learners have shown to be often passive in language classrooms and lessons. In this current era of globalization, there is a need for English instructors to improve their inactive learners' confidence so as they can be capable of participating actively in oral classroom activities. Based on this issue, the study aimed to investigate the strategies that can be put in place to improve the learner's confidence in speaking. The sample of the study involved seven (7) male students and 39 females of the Bachelor of Elementary Education (BEEd) in Samar State University. For the sake of improving learners' confidence, thirty minutes in each learning session was set aside to interview activities which lasted for a period of eight (8) consecutive weeks. The views and perceptions of the learners' confidence development were obtained by use of quantitative analysis in line the with confidence questionnaire. The findings of the study revealed that incorporation of additional speaking activities in classrooms resulted to an increase in learners's confidence. Encouraging learners to collaborate with their colleagues also improved their confidence.

\section{Introduction}

Practitioners and language experts from the area of second language teaching perceive that speaking skills play a major role and should be incorporated in in program development and creation in language teaching as for an individual to be in a position to use a foreign language then automatically he must be able to speak the language effectively. (Liu, 2001; Tsou, 2005; Van den Branden et al., 2009).

This significance relies on two factors. First, our character, our self-perception, our knowledge concerning the world, and our capability of reasoning and expressing our inner thoughts are all revealed during our speaking process in the second language. The main aim and wish of every second language learner are to be in a position to speak effectively with strangers and visitors from foreign nations in a language that they can both understand (Luoma, 2004). Secondly, the association between the participation of learners in the classroom and their academic attainment is irrefutable. From the statistics, it is evident that learners who participate actively in class usually attain higher achievement in their academics as compared to students who are inactive in class. According to Krupa-Kwiatkowski (1998), interaction incorporates individual engagement, participation, and putting into consideration activities that are believed to accelerate and initiate cognitive processes suitable to language learning.

The significance of capability to speak should therefore be keenly put into consideration by both learners and teachers without any reluctance (Turner, 2010). With my experience in teaching, I have realized that some students are fond of keeping silent during lessons. They don't like speaking English, even if they are in a position to to give the answer to a simple question, they often keep silent.

Similarly, based on past reviewed works and statistics, it can be detected that second learners most of the time look inactive during language classroom lessons. Most English language instructors encounter problems of encouraging their learners to speak in the language classroom (Tsui, 1996; White \& Lightbown, 1984). With the increase in globalization, there is a high necessity for English teachers to make sure their learners are in a position to communicate effectively and gain confidence to

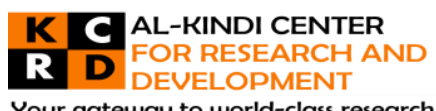

Your gateway to world-class research

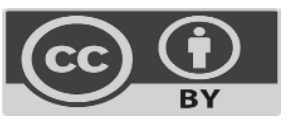

Published by Al-Kindi Center for Research and Development. Copyright (c) the author(s). This open access article is distributed under a Creative Commons Attribution (CC-BY) 4.0 license 
participate in oral classroom lessons (Liu \& Jackson, 2009). Even though not widely researched, silence during linguistic lessons has been an issue of concern in the recent past because of its growing significance in oral proficiency in learning second language circumstances. (Chen, 2003; Flowerdew et al., 2000; Jackson, 2002, 2003; MacIntyre et al., 2001; Tong, 2010). Several of these research came with one main issue which was to determine the key reason for the occurrence of the phenomena. Researchers came up with various reasons that tried to explain these phenomena and some of them included fear of being laughed at by collegues, low level of skills and proficiency in the language to be learned, past bad experience while speaking in class, cultural beliefs, and norms regarding the manner of behaving in class e.g being quiet in class depicts respect to the teacher and lack of confidence.

Because it is evident that little research has been conducted on variations in second language learners self-confidence (Maclntyre et al., 1998, p. 547), this work aimed at looking at this affective variable through research and determining if encouraging learners to collaborate with their colleagues in activities of extra speaking that is applied in the classroom would give them a main active role in the process of learning and improve their self-confidence.

The problem that the researcher recognized in her class was that most of her learners in BEEd (Bachelor of Elementary Education) were inactive during the lessons and spoke less. After investigating the issue informally, she realized that many students had issues with speaking English.

In the determination of attitude of learners concerning English learning, she asked the learners the skill they wanted to improve mostly. She realized that many of the learners wanted to improve their speaking skills but they didn't express the idea categorically. That is, they were willing to speak but did not have the confidence to speak.

According to Tarone and Yule, 1989, language instructors usually teach according to informal reviews of the requirements of their students (Tarone \& Yule, 1989), though, the researcher thought that data from the informal conversation was inadequate to conclude that lack of confidence was the main issue that hindered learners to speak. The researcher decided to do an investigation of the attitude of learners concerning speaking skills by gathering information from a needs analysis questionnaire as shown in (Appendix A) which she created for this task. Data from the needs analysis depicted that a large percentage of the learners were concerned in speaking but they didn't have enough confidence to speak English. Also, the learners stated that their inability to speak English could be a result of inadequate speaking experience or chances to be involved in second language conversation in class.

Hence, the main research question that guides this study is:

Can a second language instructor improve his/her learners' confidence in speaking in the classroom by offering their students additional speaking materials and inspiring them to be engaging in groupwork speaking activities in class?

\section{Literature Review}

According to the works of (Clement \& Kruidenier, 1985), motivation, language ability, and confidence are usually regarded as different but related learning dimensions in the second language field. According to statistics, these concepts have a direct relationship and affect each other in a manner that the change in one factor either positively or negatively impacts the other in a similar way.

In line with the works of Yashima et al. (2004), it is necessary for learners to communicate so that their communication skills can be enhanced and gain confidence, his work focused on coming up with a circular and interactive model to portray the mechanisms of learning, interest, motivation, communication, and confidence. Hence little studies have been done to investigate the issue of confidence separately, and this concept has greatly been proclaimed as an outcome of other research done on affective variables like motivation or anxiety. Although, these studies are significant as they have looked at the association between self-confidence in the ability of a language and other related factors.

Past studies have exhibited a strong link between motivation and confidence. For instance, based on the works of Clement et al. (1994), it is clear that numerous variables are associated with motivation but particularly produce enough proof to portray that self-confidence is a powerful and main process of motivation in monocultural and also multicultural communities. The researchers concluded that atmosphere and classroom activities were significant in enhancing self-confidence but also extracurricular acquaintance with the second language played some important role.

According to the works of Yashima (2002), he investigated 297 undergraduate learners and discovered that learners who were more motivated to be associated with English conversation because of their good attitude to the foreign communities have a higher level of confidence in comparison to learners who lacked the motivation. 
The proof of a stable link between anxiety and low self-confidence results in a great issue of concern of the significance of selfconfidence in learning of the second language by students. The works of Cheng et al. (1999) focuses on this particular role of self-confidence in the acquisition of a second language and state that the findings of their study provide extra support to many other studies that have examined the relationship between low-self-confidence in and anxiety related to language. They concluded that some anxious learners in L2 classes may be mainly suffering from low self-confidence in expressing themselves in the language to be learned (Cheng et al., 1999, p. 436).

With respect to Maclntyre et al. (1997), regarding L2 learning, learners possessing low self-confidence usually undervalue their potential to acquire $L 2$ and develop negative perceptions regarding their performance expectations and hence develop a feeling of insecurity during the course of learning English.

Many past research have portrayed that there is a direct association amongst the confidence of learners and their speaking characters in a second language. For instance, Lai (1994) did a study to investigate the level of confidence of Hong Kong secondary students in the use of English and factors that result in distinct confidence levels during classroom oral participation. The findings of the research revealed that majority of the respondents believed that inadequate confidence in using English to communicate in the classroom was the main issue.

Similarly, another research done by Maclntyre et al. (1998) revealed that self-confidence greatly determines the willingness of learners to communicate in a second language. Based on their findings, affective factors like intergroup climate, motivation, selfconfidence, and motivation determine the willingness to communicate, and issues related to self-confidence including general self-confidence in the second language are of great importance in the determination of the student's willingness to communicate.

Yashima et al. (2004) investigated high school learners who went abroad to study English courses. Many factors affected the students' ability to speak such as inadequate confidence in using a foreign language and this made it hard to initiate communication and interaction with native speakers due to lack of confidence.

As a result of negative consequences, some researchers made an attempt of coming up with solutions to curb the issue of learners' lack of confidence in second language classrooms. In line with the works of Burden (2004), it is evident that a larger percentage of freshmen surveyed were not confident while speaking English. He recommended that instructors apply cooperative instead of competitive goal structures as a way of developing interdependencies amongst students to enhance their self-confidence.

According to Ewald (2007), it is evident that approximately half of the learners revealed that they had an average confidence level in their upper-stage classes. She claimed that what was more surprising is that even though they majored in Spanish, only twelve of the learners out of twenty-one claimed that they were more confident currently concerning their language ability than before. She suggested and concluded that instructors should play a major role to develop the confidence and perception of upper-level students. That is, when learners make a correct attempt, an instructor must motivate and convince them to continue with the progress. Give them an assurance that it is normal to make a mistake and individuals learn through mistakes.

Another research that was conducted by Tong (2010), it was revealed that for the sake of improving learners confidence, there is a need of setting aside a suitable amount of time for learners to form their feedback to instructors questions or to come up with their questions (p. 250).

\section{Methodology}

\subsection{Participants}

Participants involved in this research involved seven (7) male and 39 female students of the Bachelor of Elementary Education (BEEd) in Samar State University. They were between 16 and 21 years old and were actually mentees of the teacher-researcher in her English 120-Communication Arts class in the second semester of the school year 2017-2018. They had two 90-minute sessions (1 hour and 30 minutes per meeting) each week for a duration of a 16-week semester.

\subsection{Context}

The participants of the study had some little knowledge and skills based on English grammar but were reluctant and passive to speak the second language. In line with Jahangard (2007), one of the key factors behind this reason of the inability of learners to use English is that the learners' oral and listening skills are not emphasized and put into consideration in language textbooks particularly in high school. The skills are not assessed in the exams for joining universities and also in the end exams in the course of the three years duration of senior high school and one year before university education. Instructors concentrate less on 
speaking and listening skills as compared to grammar, writing, and reading skills. Their main aim is to make learners pass the assessment and exams and since learners' productive abilities are not assesed anywhere in the syllabus, most of the instructors omit the concept in the textbooks.

Therefore, it is not a unique thing to see the respondents of this study, even those at the university level lacking the adequate techniques to use the English language effectively (Farhady et al., 1994). They are outcomes of the curriculum system that denies learners opportunities to actively participate in the classroom.

\subsection{Materials}

Several past studies have depicted that second language learners' inadequate confidence is a result of a lack of practice of speaking. For instance, with regard to Kubo (2009), the inadequate chance to practice speaking is a key factor that results in learners' lack of confidence. That is, the lack of confidence of learners may be a result of the emphasis that is provided to approachable language skills in the classroom (Biggs, 1994).

According to Benson (1991), the learners that participated in his research had minimal exposure to English. But what was more surprising with his study is that even though the students exhibited little exposure to English, they portrayed little confidence in their potential to deal with speaking skills. The works of Schneider (2001), agree with past studies that revealed that with little chances of Japanese college students to do English speaking exercise, overall they don't have the confidence to speak regardless of being exposed to the target language for at least six years.

In this manner, because the teacher-researcher aimed to enhance the confidence of her learners in speaking, they had to set aside more time to practice speaking while with their peers and friends. Thereby, she applied one of the books that are authorized on speaking in which its activities were in line with true-world events. Speaking Extra (Gammidge, 2004) is a very significant book that contains materials for extra classroom work. The content of the book assists students to speak confidently and conduct main social transactions (Gammidge, 2004, p. 7).

Furthermore, she also incorporated communicative activities like role play, dialogue, scenario, simulations (telephone conversation, interviews, asking and giving directions, following instructions, reporting information, etc.), and other speaking tasks and games to make her students motivated and enjoy every class session in English 120 - Communication Arts. Nunan (2003) proclaims that in the past 25 years, the communicative tasks have appeared to be the main foundation in language curricula development and also as a component for accelerating the process of acquisition of a second language. He focuses on the impact of the communicative tasks where students require to interact with the inside and outside classroom environment which enhances the process of language acquisition. This technique of language teaching has the following characteristics:

1. interaction in the target language should be emphasized on learning to communicate;

2. The involvement of authentic texts into the learning circumstance;

3. The giving of chances to students to concentrate on both the language and learning process of the language;

4. An improvement of student's personal experiences as significant contributing factors to classroom learning; and

5. A trial to connect classroom language learning with the language that is used outside the classroom.

\subsection{Procedure}

The ordinary technique used in the book, Speaking Extra (Gammidge, 2004), to involve learners in communication is "interview." This technique involves asking a question to one student by either a single or many interviewers. Interviews were applied to make each sure person is engaged in the activity and obtain personal data, likes and dislikes, or amazing previous experiences. In the process of the interview, the respondents were to add additional information to the answers they were to provide according to questions and the interviewers used the response as a basis of asking more questions.

According to Meng (2009), this technique is very important as it enables the continuation of dialogue and thereby supporting speaking activity (p. 220). The teacher-researcher began to include supplementary speaking activities in the classroom as from week 3 to week 16 of the semester - started on November 16, 2018, and ended on March 4, 2019 (covering 28 sessions during 14 weeks). 30 minutes of each lesson was set aside for extra speaking activities as a substitute for reporting topics or reading lectures in which the learners were required to do a presentation in class. The reporting or oral presentation via discussion method was prescribed by the teacher-researcher, as manifested in her course syllabus, and was required to enhance the speaking proficiency of learners. 


\subsection{Data Type}

The research made use of the confidence questionnaire so as to obtain a deeper understanding of the development of respondents' confidence and the results of the extra-curricular speaking activities on their development. The following section gives a detailed description.

\subsection{Confidence in Speaking Questionnaire}

The 'Confidence in Speaking Questionnaire' was implemented by Griffee (1997) for purposes of determining students' levels of confidence for general university learners. It is regarded as the oldest questionnaire to be published concerning second language confidence. Griffee's (1997) confidence questionnaire was a result of a deeper investigation into the variable of selfconfidence. He gave evidence of the validity and reliability of his questionnaire.

Griffee (1997) postulated three factors that determine confidence in English speaking. They include assurance, willing engagement, and ability. He stated that ability majorly involves grammar command, pronunciation, and vocabulary. Assurance involves a feeling of comfort and security while speaking in English and willing engagement as an individual who feels good to engage in English communication with English foreign speakers (p. 187).

His questionnaire is in line with the three factors of confidence and is suitable to the teacher-researchers inquiry well because it enabled her to deeply investigate her learners' confidence sense.

At the beginning of the semester, she allowed the learners to fully fill the Griffee's (1997) Confidence in Speaking English as a Foreign Language Questionnaire as depicted in (Appendix B). she distributed the questionnaires again to the learners two weeks before the semester came to completion to determine if the level of confidence of learners in speaking English was altered. The questionnaire was made up of 12 items which gave responses to statements like I can speak English with ease or I love speaking in English.

A five-point Likert scale followed every item where learners were required to state whether they strongly agree or disagree. The quantitative analysis comprised of the merging and assembling of the results that were obtained from the questionnaires at the start and end of the semester. Data was then placed in percentages that showed the degree of agreement or disagreement with the statements and the numerical being rounded off to the nearest whole number.

\section{Results}

\subsection{Confidence Questionnaire Results}

Results of the three (3) factors of four (4) questionnaire substances are highlighted below. The three factors included willing engagement, assurance, and ability (as depicted in Griffee's confidence construct). The teacher-researcher initially investigated the factors independently through a comparison of the findings from the questionnaire at the beginning and the end of the semester and giving a description of the items in each factor. She thereafter examined the three factors, in general, to determine which group of particular factors of confidence was strengthened mostly during the semester.

\subsection{Ability}

Overall, learners claimed that they had a greater ability to speak in English in week 14 as compared to the third week. About $21 \%$ of the learners supported the idea that I can be interviewed in English (item 1), while $70 \%$ were undecided and $9 \%$ protested this idea in week 3 . The agreement of learners to this declaration increased to $91 \%$ at the semester end.

Item four of the questionnaire which was based on discussing in English with native speakers portrays the second-highest improvement in confidence in this factor (68\%). The agreement of learners with statements greatly improved from $19 \%$ in the third week to $87 \%$ in the $14^{\text {th }}$ week. This shows that continuous giving of opinions to speakers who are non-native successfully resulted to gain in confidence in providing opinions to English speakers who are native too.

\section{Table 1. Frequency and Percentage of Students' Responses on the Confidence in Speaking Questionnaire}

\begin{tabular}{|c|c|c|c|c|c|c|c|c|c|c|c|c|c|c|c|c|c|c|c|c|}
\hline \multirow{3}{*}{ Items } & \multicolumn{4}{|c|}{ SA } & \multicolumn{4}{|c|}{ A } & \multicolumn{4}{|c|}{$\mathbf{U}$} & \multicolumn{4}{|c|}{ D } & \multicolumn{4}{|c|}{ SD } \\
\hline & \multicolumn{2}{|c|}{ Beg. } & \multicolumn{2}{|c|}{ End } & \multicolumn{2}{|c|}{ Beg. } & \multicolumn{2}{|c|}{ End } & \multicolumn{2}{|c|}{ Beg. } & \multicolumn{2}{|c|}{ End } & \multicolumn{2}{|c|}{ Beg. } & \multicolumn{2}{|c|}{ End } & \multicolumn{2}{|c|}{ Beg. } & \multicolumn{2}{|c|}{ End } \\
\hline & $\mathbf{n}$ & $\%$ & $\mathbf{n}$ & $\%$ & $\mathbf{n}$ & $\%$ & $\mathbf{n}$ & $\%$ & $\mathbf{n}$ & $\%$ & $\mathrm{n}$ & $\%$ & $\mathbf{n}$ & $\%$ & $\mathbf{n}$ & $\%$ & $\mathbf{n}$ & $\%$ & $\mathbf{n}$ & $\%$ \\
\hline 1 & & & 5 & $11 \%$ & 10 & $21 \%$ & 38 & $80 \%$ & 33 & $70 \%$ & 4 & $9 \%$ & 4 & $9 \%$ & & & & & & \\
\hline 2 & & & 7 & $15 \%$ & 24 & $51 \%$ & 34 & $72 \%$ & 15 & $32 \%$ & 6 & $13 \%$ & 8 & $17 \%$ & & & & & & \\
\hline 3 & & & 20 & $42 \%$ & 39 & $83 \%$ & 23 & $49 \%$ & 8 & $17 \%$ & 4 & $9 \%$ & & & & & & & & \\
\hline 4 & 2 & $4 \%$ & 15 & $32 \%$ & 7 & $15 \%$ & 26 & $55 \%$ & 30 & $64 \%$ & 6 & $13 \%$ & 8 & $17 \%$ & & & & & & \\
\hline
\end{tabular}




\begin{tabular}{|l|l|l|l|l|l|l|l|l|l|l|l|l|l|l|l|l|l|l|l|l|}
\hline $\mathbf{5}$ & 1 & $2 \%$ & 12 & $26 \%$ & 16 & $34 \%$ & 34 & $72 \%$ & 25 & $53 \%$ & 1 & $2 \%$ & 5 & $11 \%$ & & & & & & \\
\hline $\mathbf{6}$ & 1 & $2 \%$ & 8 & $17 \%$ & 3 & $6 \%$ & 29 & $62 \%$ & 31 & $67 \%$ & 10 & $21 \%$ & 10 & $21 \%$ & & & 2 & $4 \%$ & & \\
\hline $\mathbf{7}$ & & & 2 & $4 \%$ & 3 & $6 \%$ & 24 & $51 \%$ & 30 & $64 \%$ & 21 & $45 \%$ & 14 & $30 \%$ & & & & & & \\
\hline $\mathbf{8}$ & 2 & $4 \%$ & 15 & $32 \%$ & 13 & $28 \%$ & 25 & $53 \%$ & 17 & $36 \%$ & 7 & $15 \%$ & 14 & $30 \%$ & & & 1 & $2 \%$ & & \\
\hline $\mathbf{9}$ & & & 4 & $9 \%$ & 19 & $40 \%$ & 32 & $68 \%$ & 24 & $51 \%$ & 11 & $23 \%$ & 4 & $9 \%$ & & & & & & \\
\hline $\mathbf{1 0}$ & & & 14 & $30 \%$ & 38 & $81 \%$ & 33 & $70 \%$ & 3 & $6 \%$ & & & 2 & $4 \%$ & & & 4 & $9 \%$ & & \\
\hline $\mathbf{1 1}$ & & & 4 & $9 \%$ & 20 & $43 \%$ & 28 & $59 \%$ & 19 & $40 \%$ & 15 & $32 \%$ & 8 & $17 \%$ & & & & & & \\
\hline $\mathbf{1 2}$ & & & 8 & $17 \%$ & 10 & $21 \%$ & 24 & $51 \%$ & 20 & $43 \%$ & 15 & $32 \%$ & 17 & $36 \%$ & & & & & \\
\hline
\end{tabular}

At the start of the semester, only $6 \%$ of the learners agreed with the statement that they are capable of showing an Englishspeaking visitor around the university and answer his questions (item 7). At the end of the semester, their agreement level increased to $55 \%$. This showed the third-highest increase level concerning this set, exhibiting an increase of $49 \%$.

Based on item 9 of the questionnaire which regarded giving of personal opinion in English when speaking to a native speaker, there was a $37 \%$ increase in confidence level. The level of agreement increased from $40 \%$ at the beginning of the semester to $77 \%$ during the $14^{\text {th }}$ week. This particular finding shows that extra group work activities offered learners a chance to air their opinions with more confidence even while communicating with a foreign speaker.

With regard to the findings, the teacher-researcher argues that by the provision of regular opportunities to do practice appropriate speaking activities in a group and communicate freely, the learners gained a greater ability and confidence while speaking in English. In a comparison of the findings of the questionnaire in week 3 and 14, there was an average increase of 56\% for the four items that is (items $1,4,7$, and 9) in this factor.

\subsection{Assurance}

Overall, learners portrayed a moderate increase in assurance while speaking English. The item that displayed the lowest increase in this set was item 3, which was talking about the love of speaking English with an increase of $8 \%$ only. At the start of the semester, learners' agreement with this statement was at $83 \%$ and their level of agreement with the statement increased to $91 \%$ at the semester end. Because all the learners were to partake teacher education program, it can be assumed that they were motivated to speak English prior to beginning their study. Therefore, this slight improvement is reasonable.

Item 6 was the most noticeable in this set. It talked about the easiness of speaking English. The findings from this item revealed that learners believed that speaking English was easier to speak by an increase of $71 \%$ averagely. $8 \%$ of the learners agreed with the fact that they are capable of speaking English easily in week 3 which significantly increased to $79 \%$ by week 14 .

Item 11 depicted the third-highest increase which was (25\%) improvement in confidence in this factor. The item talked about speaking to a group of people in English. $43 \%$ of the respondents agreed with this idea at the start of the semester and the percentage increased to $68 \%$ at the end of the semester.

Based on relaxing when speaking English, the findings revealed that students felt more relaxed while speaking in English reporting a percentage increase of $47 \%$ for item 12 which talked about the extend of relaxation of learners while talking in English. The degree of increase ranged from $21 \%$ at the beginning of the semester to $68 \%$ at the end of the semester. Relating to the results of the questionnaire of the $3 r d$ and $14^{\text {th }}$ week, there was an average increase of $38 \%$ in assurance for items $3,6,11$, and 12 .

\subsection{Willing Engagement}

Similarly, students showed a great increase in willing engagement just like in assurance. Based on (item 2) with talked about the love of studying in an English-speaking country, approximately half of the learners (51\%) agreed with the statement at the beginning of the semester. At the end of the semester, their level of agreement increased to $87 \%$. There was a $36 \%$ average increase in general.

The learners averagely reported a percentage of 62 in agreement to the statement I feel more cheerful when speaking English depicting that learner's related extra speaking activities with loveliness. As compared to the start of the semester where $36 \%$ of the learners agreed with the statement I feel cheerful when I speak in English (item 5), the percentage greatly increase to $98 \%$ at the end of the semester exhibiting the highest improvement in this set. 
With regard to item 8 of the questionnaire which talked about saying something to other people in English daily, the findings indicated that a larger percentage of the learners say something to their peers on a daily basis in English. The range of the increase in the percentage of saying something varied from $32 \%$ at the start of the semester to $85 \%$ during the semester end. This portrayed the second-highest percentage increase (53\%) for this set. This showed that most of the students were willing to say something in English to other people even if it was not academic-related. Even though group work activities were conducted in a 30-minute setting two times a week, many learners got a chance of speaking English daily suggesting that the activities provided them more confidence to do that.

Item 10 recorded the lowest average increase in this factor. It talked about looking for chances to speak English. This is because a large percentage of $81 \%$ had already agreed to this statement at the beginning of the semester whereby the percentage increased to $100 \%$ at the end of the term. In general, the learners felt more confident to speak in English at the end of the term as compared to the start of the term, indicating a $42 \%$ average improvement in willingness to engage in conversations concerning English for items 2, 5, 8, and 10.

\subsection{Overall Questionnaire Results}

Based on all three aspects which included willing engagement, assurance, and ability, there was an indication of an average increase of $45 \%$ at the end of the semester compared to the beginning of the term by the learners. For the sake of obtaining a more detailed picture of the finding, the teacher-researcher chose and did an analysis of the most the and the slightest noticeable items in every three sets.

In Set 1 (ability), she chose item 1 (I can be interviewed in English); in Set 2 (assurance), she selected item 6 (I can speak English easily); and in the 3rd Set (willing engagement), she chose item 5 (When I speak English, I feel cheerful) as the greatest noticeable items because of their increase in average. With regard to these 3 items, and their highest percentage average in confidence increase (68\%) shows that regular practice of speaking English in group work activities made students find it easy to speak English.

Similarly, the teacher-researcher chose three of the least noticeable items in every set. in Set 1 (ability), she chose element 9 (when talking to a foreign speaker, I am capable of raising my opinion in English); in the second Set (assurance), she selected item 3 (I like speaking English); and in the third Set (willing engagement), she chose item 10 (I search for opportunities to speak English) as the minimum noticeable items because of their increase averagely. The combination of the three items generally depicted a low increase in confidence averagely (21\%).

Learners stated the smallest sum of improvement in confidence (8\%) in item 3. There was a 37\% increase in confidence for item 9 and a $19 \%$ increase average increase for item 10 in confidence. These results reveal that including extra speaking activities in the class had a little impact in improvement in confidence in giving opinion by the use of English while communicating with foreigners nor the activities boosted a great increase in confidence in looking for chances to speak English. Also, the findings reveal that extra speaking activities had little impact in improving learners' desire to speak English overall since the majority of them (51\%) were having a positive attitude concerning English speaking prior to the start of their study.

Based on the results of week 14 and week three questionnaires, item 3 which was about the likeness of speaking in English, and item 10 concerning looking for chances to speak in English obtained the two lowest increases in average that is (8\% and $19 \%$, respectively) in all the 12 items of the questionnaire. This is as a result of the highest average at the beginning of the term (83\% and $81 \%$, respectively), and hence a lower possibility of a greater increase in average at the end of the semester.

Similarly, there was a great level of improvement in average in item 6 (the ability to speak English with ease) by $(71 \%$ and $70 \%$, respectively) in all the questionnaire items that were $12 \mathrm{in} \mathrm{total.} \mathrm{This} \mathrm{is} \mathrm{as} \mathrm{a} \mathrm{result} \mathrm{of} \mathrm{the} \mathrm{lower} \mathrm{average} \mathrm{levels} \mathrm{that} \mathrm{were} \mathrm{indicated}$ at the beginning of the semester ( $8 \%$ and $21 \%$, respectively), and hence the probability of a great change in confidence level at the end of the semester.

\section{Conclusion}

The research concentrated on the confidence of learners in speaking English in class an aspect that is regarded as very significant especially during this current era of globalization. It is clear from the study that there is still much that has to be done to make sure second language learners use the English language efficiently (Curtis, 2001, p. 69). There was the incorporation of extra speaking activities into the class to enhance the performance of the learners and their confidence. This was done through the establishment of group work. the findings of the study revealed that the level of confidence of learners improved in cooperative settings. That is, there was a direct association between confidence and groupwork activities. Also, the results showed that instructional methodology focusing on colleague collaboration as a mechanism of improving the learners' ability to speak has a 
higher possibility of resulting in confidence. In addition, the results of this research suggested that second language teachers must look for ways to involve the collaboration of learners in the subject language as a segment of their program and syllabus design to assist them in gaining confidence in speaking English.

\section{References}

[1] Benson, M. (1991). Attitudes and motivation towards English: A survey of Japanese freshmen. RELC Journal, 22(1), 34-48.

[2] Biggs, J. (1994). From theory to practice: A cognitive systems approach. Higher Education Research and Development, 12, 73-86.

[3] Biggs, J., \& Moore, P. J. (1993). The process of learning. Sydney, Australia: Prentice Hall of Australia.

[4] Burden, P. (2004). The teacher as facilitator: Reducing anxiety in the EFL university classroom. JALT Hokkaido Journal, 8, 3-18.

[5] Chen, T. (2003). Reticence in class and on-line: Two ESL students' experiences with communicative language teaching. System, 31, $259-281$.

[6] Cheng, Y., Horwitz, E. K., \& Schallert, D. L. (1999). Language anxiety: Differentiating writing and speaking components. Language Learning, 49(3), 417-446.

[7] Clement, R., Dornyei, Z., \& Noels, K. (1994). Motivation, self-confidence and group cohesion in the foreign language classroom. Language Learning, 44, 417-448.

[8] Curtis, A. (2001). Hong Kong secondary school teachers' first experiences of action research. The PAC Journal, 1(1), 65-78.

[9] Ewald, J. D. (2007). Foreign language learning anxiety in upper-level classes: Involving students as researchers. Foreign Language Annals, 40(1), 122-142.

[10] Farhady, H., Jafarpoor, A., \& Birjandi, P. (1994). Testing language skills: From theory to practice. Tehran, Iran: SAMT Publications.

[11] Flowerdew, J., Miller, L., \& Li, D. (2000). Chinese lecturers' perceptions, problems and strategies in lecturing in English to Chinese-speaking students. RELC Journal, 31(1), 116-138.

[12] Gammidge, M. (2004). Speaking extra. Cambridge, England: Cambridge University Press.

[13] Griffee, D. T. (1997). Validating a questionnaire on confidence in speaking English as a foreign language. JALT Journal, $19(2), 177-197$.

[14] Jackson, J. (2002). Reticence in second language case discussions: Anxiety and aspirations. System, 30(1), 65-84.

[15] Jackson, J. (2003). Case-based learning and reticence in a bilingual context: Perceptions of business students in Hong Kong. System, 31, 457-469.

[16] Jahangard, A. (2007). Evaluation of EFL materials taught at Iranian public high schools. The Asian EFL Journal, 9(2), 130-150.

[17] Kubo, M. (2009). Extensive pair taping for college students in Japan: Action research in confidence and fluency building. Accents Asia, 3(1), $36-68$.

[18] Krupa-Kwiatkowski, M. (1998). "You shouldn't have brought me here!": Interaction strategies in the silent period of an inner-direct second language learner. Research on Language and Social Interaction, 31(2), 133-175.

[19] Lai, C. (1994). Communication failure in the language classroom: An exploration of causes. RELC Journal, 25, 99-129.

[20] Liu, J. (2001). Asian students' classroom communication patterns in American classrooms. Westport, CT: Greenwood Publishing.

[21] Liu, M., \& Jackson, J. (2009). Reticence in Chinese EFL students at varied proficiency levels. TESL Canada Journal, 26(2), 65-81.

[22] Luoma, S. (2004). Assessing speaking. Cambridge, England: Cambridge University Press.

[23] Macintyre, P. D., Baker, S. C., Clement, R., \& Conrod, S. (2001). Willingness to communicate, social support, and language-learning orientations of immersion students. Studies in Second Language Acquisition, 23, 369-388.

[24] Macintyre, P. D., Clement, R., Dornyei, Z., \& Noels, K. A. (1998). Conceptualizing willingness to communicate in a L2: A situational model of L2 confidence and affiliation. Modern Language Journal, 82, 545-562.

[25] Maclntyre, P. D., Noels, K. A., \& Clement, R. (1997). Biases in self-ratings of second language proficiency: The role of language anxiety. Language Learning, 47, 265-287.

[26] Meng, F. (2009). Encourage learners in the large class to speak English in group work. English Language Teaching, 2(3), $219-224$.

[27] Nunan, D. (1992). Collaborative language learning and teaching. Cambridge, England: Cambridge University Press.

[28] Nunan, D. (1998). Syllabus design. Oxford, England: Oxford University Press.

[29] Nunan, D. (2003). The impact of English as a global language on educational policies and practices in the Asia-Pacific region. TESOL Quarterly, 37, 4, Winter 2003.

[30] Schneider, P. H. (2001). Pair taping: Increasing motivation and achievement with a fluency practice. TESL-EJ, 5(2), 1-32.

[31] Tong, J. (2010). Some observations of students' reticent and participatory behavior in Hong Kong English classrooms. Electronic Journal of Foreign Language Teaching, 7(2), 239-254.

[32] Tsou, W. (2005). Improving speaking skills through instruction in oral classroom participation. Foreign Language Annals, 38(1), 46-55.

[33] Turner, J. (2010). The impact of pupil-set targets on achievement in speaking: An action research project involving a mixed-sex Year 9 German class. Journal of Trainee Teacher Educational Research, 1, 1-34.

[34] Van den Branden, K., Bygate, M., \& Norris, J. M. (Eds.) (2009). Task-based language teaching: A reader. Amsterdam, Netherlands: John Benjamin Publishing.

[35] Yashima, T. (2002). Willingness to communicate in a second language: The Japanese EFL context. Modern Language Journal, 86, 55-66.

[36] Yashima, T., Zenuk-Nishide, L., \& Shimizu, K. (2004). The influence of attitudes and effect on willingness to communicate and second language communication. Language Learning, 54(1), 119-152. 


\section{APPENDICES}

Appendix A

\section{Needs Analysis Questionnaire}

(Adapted from Nunan, 1998; and Griffee, 1997)

Name:

Age:

Field of Study:

(optional)

1. Do you like to learn English by:

Listening

2. Do you like to:

3. Do you like to learn English by: Conversation

Books Watching T.V.

$$
\begin{aligned}
& \text { Reading } \\
& \square \text { Speaking } \quad \square \text { Writing }
\end{aligned}
$$

Study grammar $\square$ Learn new words

Practice conversation

Cassettes $\quad \square$ Games

Studying English

4. Do you like to learn by talking to friends in English? $\square$ Yes $\quad \square$ No

5. Do you like to learn English words by:

Seeing them $\quad \square$ Using them

6. Do you like to learn English with the whole class?

Yes $\quad \square$ No

7. Do you like to learn English by talking in pairs?

$\square$ Yes

$\square$ No

8. Do you speak English out of the class?

9. Do you feel happy when you speak English?

10. Do you look for chances to speak English?

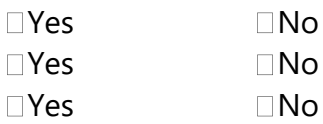

11. Do you have enough confidence to speak to a group of people in English?

$\square$ Yes $\quad \square$ No

12. Do you feel relaxed when you speak in English?

13. How do you learn best?

$\begin{array}{cc}\square \text { Alone } & \square \text { Pairs } \\ & \square \text { Small group } \quad \square \text { Class } \\ & \square \text { Outside class }\end{array}$

14. What do you feel are the most important things for you to learn in: Short term: Long term:

\section{Appendix B}

Confidence in Speaking Questionnaire (Adapted from Griffee, 1997)

Directions: Encircle the option that best responds to your perception on the following statements.

1. I can be interviewed in English.

$$
\text { Strongly Agree Agree Undecided Disagree Strongly Disagree }
$$

2. I would like to study in an English speaking country.

$$
\text { Strongly Agree Agree Undecided Disagree Strongly Disagree }
$$

3. I like speaking English.

Strongly Agree Agree Undecided Disagree Strongly Disagree


4. I can discuss in English with native speakers.
Strongly Agree Agree
Undecided
Disagree Strongly Disagree

5. When I speak English, I feel cheerful.
Strongly Agree Agree
Undecided
Disagree Strongly Disagree

6. I can speak English easily.
Strongly Agree Agree
Undecided
Disagree Strongly Disagree

7. I can show an English speaking visitor around the campus and answer questions.
Strongly Agree Agree
Undecided
Disagree Strongly Disagree

8. I say something to other people in English every day.
Strongly Agree Agree
Undecided
Disagree Strongly Disagree

9. I can give my opinion in English when talking to a native speaker.
Strongly Agree Agree
Undecided
Disagree Strongly Disagree

10. I look for chances to speak English.

Strongly Agree Agree Undecided Disagree Strongly Disagree

11. I will speak to a group of people in English.

Strongly Agree Agree Undecided Disagree Strongly Disagree

12. I am relaxed when speaking English.

Strongly Agree Agree Undecided Disagree Strongly Disagree

